\title{
Alpha-1-microglobulin: an indicator protein for renal tubular function
}

\author{
H YU, Y YANAGISAWA, MA FORBES, EH COOPER, RA CROCKSON,* \\ ICM MacLENNAN* \\ From the Unit for Cancer Research, University of Leeds, and the *Department of Immunology, University of \\ Birmingham
}

SUMMARY A comparison of urinary $\alpha_{1}$-microglobulin concentrations to the behaviour of other indicators of renal tubular disorders, $\beta_{2}$-microglobulin, retinol-binding protein and $\mathrm{N}$ acetyl- $\beta$-D-glucosaminidase (NAG) has been made. In acute tubular disorders the concentrations of urinary $\beta_{2} \mathrm{M}$ and RBP are highly correlated $(\mathrm{r}=0.89)$ but this is less marked for $\alpha_{1} \mathrm{M}$ and $\beta_{2} \mathrm{M}(\mathrm{r}=0.55)$ and $\alpha_{1} \mathrm{M}$ and RBP $\mathrm{r}=0.48$. NAG tends to run a parallel course to $\alpha_{1} \mathrm{M}$ concentrations but lags behind the recovery of low molecular weight protein reabsorption following injury of the tubular cells.

The concentrations of $\alpha_{1} \mathrm{M}$, and in particular its stability at low $\mathrm{pH}$ suggest that this protein may be useful in screening for tubular abnormalities and detecting chronic asymptomatic renal tubular dysfunction.

Urinary $\alpha_{1} \mathbf{M}>15 \mathrm{mg} / \mathrm{g}$ creatinine is strongly suspicious of a proximal tubular dysfunction. The distinction between pure tubular proteinuria and mixed glomerular and tubular proteinuria requires further analysis.

The studies of low molecular weight proteins isolated from the urine of patients with renal tubular damage by Berggård and his colleagues have resulted in a purification of $\beta_{2}$-microglobulin $\left(\beta_{2} M\right),{ }^{1}$ free light chains, ${ }^{2}$ retinol-binding protein $(\mathrm{RBP})^{3}$ and $\alpha_{1}$-microglobulin $\left(\alpha_{1} \mathrm{M}\right){ }^{4}$ These low molecular weight proteins ( $<33000$ daltons) share the property of being readily filtered by the glomerulus and reabsorbed and catabolised by the proximal tubular cells. ${ }^{5}$ The measurement of urinary $\beta_{2} \mathrm{M}$ has been widely advocated as an indicator of tubular proteinuria, mainly as the result of the performance of this analyte as a sensitive marker of tubular damage in cadmium ${ }^{6}$ and mercury poisoning ${ }^{7}$ and more recently in following the nephrotoxic action of drugs. ${ }^{89}$ However, $\beta_{2} \mathbf{M}$ loses its antigenicity at $\mathrm{pH}<6.0$ and in routine clinical practice can lead to an underestimate of the intensity of low molecular weight proteinuria. Due to its stability in urine, RBP has been suggested to be used as a marker of tubular dysfunction. ${ }^{10}$ There is considerable literature on the increased urinary excretion of enzymes of tubular origin, especially $\mathrm{N}$ acetyl- $\beta$-D-glucosaminidase (NAG) ${ }^{12} 13$ and alanine Accepted for publication 20 October 1982 aminopeptidase (AAP) ${ }^{14}$ as indicators of tubular disorders especially after exposure to aminoglycosides. However, it is still uncertain which of these indicators of tubular function is most useful for routine use or whether their selection depends on the clinical condition being investigated.

It is evident that urinary $\alpha_{1} \mathbf{M}$ concentrations can be high in cadmium poisoning ${ }^{1}$ and in renal failure ${ }^{15-17}$ but so far there appears to be little information on how it relates to the spectrum of urinary analytes whose concentration can be increased in tubular disorders. $\alpha_{1} \mathbf{M}$ is a glycosylated protein of molecular weight estimated to be between 26000 and 33000 daltons according to the type of measurement $^{118}$ containing 167 amino acids. ${ }^{19}$ The liver is probably the main site of synthesis. ${ }^{20}$ Apart from severe liver disease ${ }^{20}$ when $\alpha_{1} \mathrm{M}$ can be low and in renal failure where the levels are raised ${ }^{15-17}$ the blood concentrations of $\alpha_{1} \mathrm{M}$ undergo little change in many forms of inflammatory and neoplastic diseases. ${ }^{1121}$ In this paper we describe its blood concentrations and urinary excretion in diseases associated with acute or chronic tubular dysfunction and how its concentrations compare with other indicators of tubular activity. 


\section{Patients and methods}

Serum samples were obtained from volunteer blood donors giving one or two donations per year and representative populations of patients with diseases that may influence the excretion of $\alpha_{1} \mathrm{M}$ in the urine. The sera were stored at $-20^{\circ} \mathrm{C}$.

Random urine collections were used for the majority of the studies. The concentration of the various analytes was adjusted for the urinary creatinine concentration. $\alpha_{1} \mathrm{M}, \mathrm{RBP}$ and $\beta_{2} \mathrm{M}$ concentrations were measured by single radial immunodiffusion (RID) ${ }^{22}$ using antisera and standards provided by Behringwerke, Marburg/Lahn, Germany ( $\alpha_{1} M$ and RBP) or purchased from Dako Immunoglobulins-a/s, Copenhagen, Denmark $\left(\beta_{2} M\right)$. A urinary light chain assay was performed at the Department of Immunology, University of Birmingham and expressed in units/l (1 unit = approximately $1 \mathrm{~g}$ ). No definitive standard is yet available; the working standard is a pool of monoclonal kappa and lambda light chains.

$\mathrm{N}$-acetyl- $\beta$-D-glucosaminidase was measured by a fluorimetric method as described by Leback and Walker ${ }^{23}$ and Price et al.$^{24}$ Two hundred units (1 unit $=1 \mathrm{nmol} / \mathrm{h} / \mathrm{mg}$ creatinine) was taken as the upper limit of normal. Urinary creatinine was measured by Jaffe's method, adapted for use on a Pye Unicam Auto Chemistry Unit; serum creatinine concentrations taken from routine hospital analyses.

SDS polyacrylamide disc gel electrophoresis (SDS-PAGE) was carried out using $7 \%$ gel. Dialysed urine $(20 \mu \mathrm{l})$ with a protein concentration adjusted to $10 \mathrm{mg} / \mathrm{ml}$ was applied to the gel with bromophenol blue marker and run for about one and a half hours at $5 \mathrm{~mA}$ per gel. The gels were stained with Coomassie blue. ${ }^{25}$

The experimental design involved (a) examination of random urines from healthy medical students and laboratory staff, aged $19-55 \mathrm{yr}$, referred to as normal controls; $(b)$ the screening of the urinary $\alpha_{1} \mathbf{M}$ excretion in patients in whom there was considered to be an increased probability of tubular proteinuria; these included bladder cancer, paraplegia and patients with an ileal conduit following total cystectomy; (c) the use of this screen in subjects who might have tubular proteinuria, workers in the chemical industry being screened for bladder cancer and patients with rheumatic diseases and $(d)$ detailed studies of the evolution of acute tubular damage in burns and acute pancreatitis, and the chronic tubular damage in multiple myeloma. The latter were patients in the Medical Research Council IVth Myeloma Trial.

Only the abnormal urines as defined by an $\alpha_{1} \mathbf{M}>$ $15 \mathrm{mg} / \mathrm{g}$ creatinine were investigated in detail in the screening survey $(b$ and $c)$. In $(d)$ all urines were examined in detail whatever their $\alpha_{1} \mathrm{M}$ concentration.

A total of 2000 measurements of urinary $\alpha_{1} M$ were made during this investigation.

STABILITY OF $\alpha_{1} M$

Seven samples of urine with $\alpha_{1} \mathrm{M}$ contents $3 \mathrm{mg}-90$ $\mathrm{mg} / \mathrm{l}$ were divided into aliquots and the $\mathrm{pH}$ adjusted to 1-10 in steps of one $\mathrm{pH}$ unit. Each sample was split into two, one half stored at $4^{\circ} \mathrm{C}$ overnight, and the other half at $4^{\circ} \mathrm{C}$ for 11 days. There was hardly any change in the urine $\alpha_{1} \mathrm{M}$ concentrations of the samples stored between $\mathrm{pH} 4.0$ and $10 \cdot 0$, below $\mathrm{pH}$ 4.0 there was a loss of activity of approximately $50 \%$ as the $\mathrm{pH}$ fell to $2 \cdot 0$. This indicates the $\alpha_{1} \mathrm{M}$ is stable in urine in the pathophysiological range of urine $\mathrm{pH}$.

\section{SERUM $\alpha_{1}$ M CONCENTRATIONS}

The relation of serum $\alpha_{1} M$ concentrations to serum creatinine in a hospital population (excluding patients with myelomatosis) is illustrated in Fig. 1.

The serum values of $\alpha_{1} \mathrm{M}$ in controls, pregnancy and various diseases, but excluding patients with a serum creatinine $>200 \mu \mathrm{mol} / 1$ are shown in Table 1 . The concentrations in burns and acute pancreatitis indicate that $\alpha_{1} \mathrm{M}$ is not an acute phase reactant protein, as both these conditions are well known to provide a very powerful stimulus for the synthesis of acute phase proteins.

In multiple myeloma, in the absence of renal failure, the distribution of serum $\alpha_{1} M$ concentrations in patients with IgG myelomatosis was unimodal,

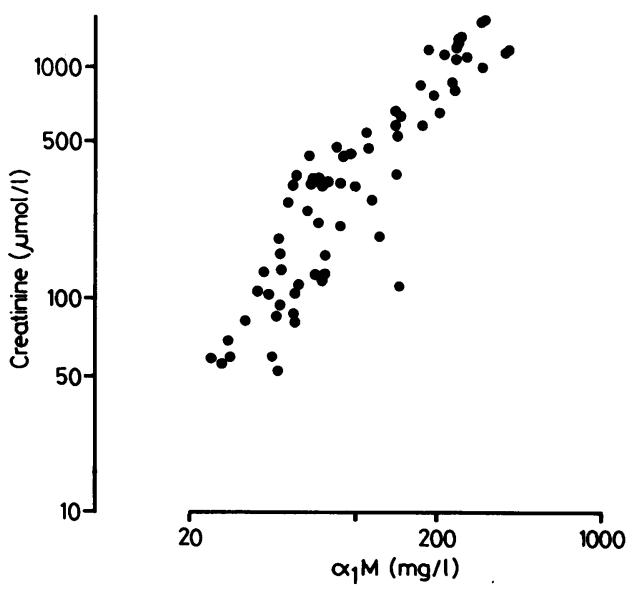

Fig. 1 Relation between serum $\alpha_{1}-M$ creatinine concentrations in a hospital population (log scales) 
Table 1 Serum $\alpha_{1}$-microglobulin concentrations in controls and patients with serum creatinine $<200$ rmolll

\begin{tabular}{lll}
\hline Condition & No of subjects $\begin{array}{l}\text { Mean } \pm S D \\
(\mathrm{mg} / \mathrm{l})\end{array}$ \\
\hline $\begin{array}{l}\text { Blood donors } \\
\quad \text { Male }\end{array}$ & 20 & $32 \cdot 0 \pm 6 \cdot 8$ \\
$\quad$ Female & 20 & $27 \cdot 9 \pm 10 \cdot 2$ \\
Pregnancy & 40 & $27 \cdot 3 \pm 5 \cdot 7$ \\
Liver disease & 65 & $33 \cdot 6 \pm 10 \cdot 2$ \\
Severe burns & 16 & $37 \cdot 6 \pm 16 \cdot 5$ \\
$\quad$ Day 1-2 & 16 & $54 \cdot 3 \pm 14 \cdot 5^{*}$ \\
$\quad$ Day 10-12 & 16 & $26 \cdot 6 \pm 11 \cdot 2$ \\
Paraplegia & 13 & $45 \cdot 4 \pm 10 \cdot 9^{*}$ \\
Bladder cancer & 16 & $33 \cdot 1 \pm 13 \cdot 3$ \\
Acute pancreatitis & &
\end{tabular}

*The raised serum $\alpha_{1} M$ is associated with a reduced glomerular filtration rate.

whilst in patients with IgA myelomatosis the distribution was generally raised and showed a marked skewness with a few values $>200 \mathrm{mg} / \mathrm{l}$. These distributions are demonstrated in Table 2.

A similar skewness in the distribution was observed in rheumatoid arthritis but was not present in the other diseases listed in Table 1. Crossed immunoelectrophoresis, with anti-IgA in an intermediate gel showed the high concentrations $\alpha_{1} \mathrm{M}$ in the serum of patients with $\operatorname{IgA}$ myelomatosis were associated with the serum $\alpha_{1} \mathrm{M}$ being in two forms: a free form with an $\alpha_{1} \mathbf{M}$ electrophoretic mobility and a form bound to IgA.

URINE ANALYSIS

The normal range of urinary $\alpha_{1} M$ excretion was $4 \cdot 2$ $\pm 5.6 \mathrm{mg} / \mathrm{l}($ mean $\pm 2 \mathrm{SD}$ ) (range $0.5-17.2 \mathrm{mg} / \mathrm{l})$ or
$4.2 \pm 6.0 \mathrm{mg} / \mathrm{g}$ (mean $\pm 2 \mathrm{SD}$ ) creatinine (range $0.2-15.0 \mathrm{mg} / \mathrm{g}$ creatinine) based on 102 normal subjects. Arbitrarily, we take $15 \mathrm{mg} / \mathrm{g}$ creatinine as a normal cut-off level.

When urinary $\alpha_{1} M$ was used to screen a population to assess the possibility of occult nephrotoxicity in $\mathbf{5 0 0}$ workers in the chemical industry, four cases of tubular proteinuria were detected and confirmed by their SDS-PAGE patterns (see Table 3).

The value of $\alpha_{1} \mathrm{M}$ in detecting unsuspected tubular proteinuria in lower urinary tract disease is illustrated by the studies of bladder cancer and paraplegic patients. In general, considering all the diseases in the study, when the urinary $\alpha_{1} M$ is $>15 \mathrm{mg} / \mathrm{g}$ creatinine and the ratio of $\alpha_{1} \mathbf{M}$ : total urinary protein is $>1: 30$, SDS-PAGE demonstrates the presence of tubular proteinuria or a mixed glomerular and tubular pattern.

The distribution of urinary NAG activities in patients with urinary $\alpha_{1} \mathrm{M}>15 \mathrm{mg} / \mathrm{g}$ creatinine is illustrated in Fig. 2. In 128 patients, 79 were found to have a NAG $>200$ units. In contrast, only 37 out of 280 patients with $\alpha_{1} \mathrm{M}<15 \mathrm{mg} / \mathrm{g}$ creatinine were found to have abnormal NAG activities. As urinary $\beta_{2} \mathrm{M}$ is degraded in acid urine $(\mathrm{pH}<5.5)$, the comparison between urinary $\beta_{2} M$ and $\alpha_{1} M$ concentrations using a RID screen could only be made in about one third to half of the samples with the exception of the paraplegics nearly all of whom have alkaline urine. Using an arbitrary cut-off for $\beta_{2} M$ of $2 \mathrm{mg} / \mathrm{l}$ as determined by the sensitivity of the RID, then the relation between a raised $\alpha_{1} M$ and $\beta_{2} M$ in the chronic disorders is shown in Table 4 . We have excluded patients with myelomatosis from the

Table 2 Distribution of serum $\alpha_{1} M$ in patients with untreated myelomatosis (serum creatinine $\left.<200 \mu m o l / l\right)$

\begin{tabular}{lllllllll}
\hline & \multicolumn{3}{l}{$\alpha_{1} M(m g / l)$} & & & \\
\cline { 2 - 8 } & $<20$ & $21-40$ & $41-60$ & $61-80$ & $81-100$ & $>100$ & Total \\
\hline No of patients with IgA myeloma & 1 & 7 & 12 & 14 & 8 & 42 & 83 \\
No of patients with IgG myeloma & 5 & 45 & 12 & - & 1 & - & 63 \\
\hline
\end{tabular}

Table 3 Percentage distribution of urinary $\alpha_{1} M$ concentrations

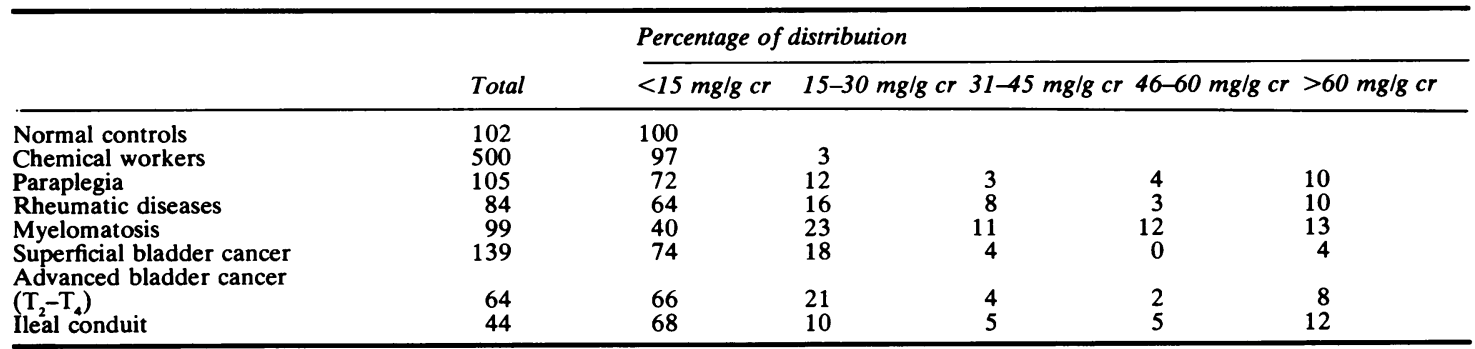

cr = creatinine 


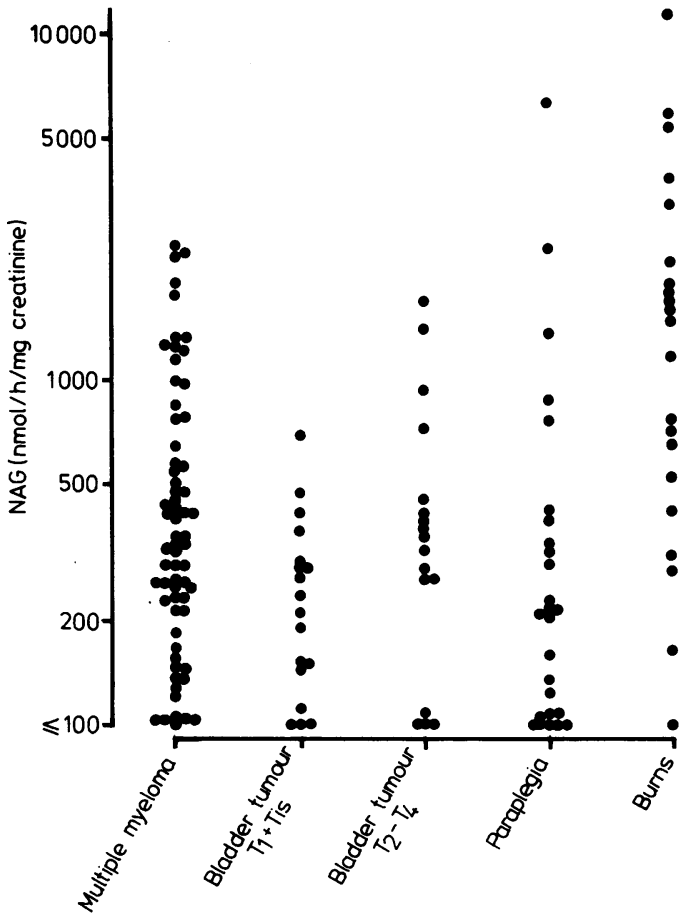

Fig. 2 Distribution of urinary NAG for patients with urinary $\alpha_{1} M$ concentrations $>15 \mathrm{mg} / \mathrm{l} . T_{1}-T_{4}=$ tumour stages; Tis = tumour in situ.

analysis shown in Table 4 as in this disease the $\beta_{2} M$ can appear in the urine due to overload from the high concentrations in the glomerular filtrate. ${ }^{31}$ When urinary $\beta_{2} M$ was detectable by RID then the correlation coefficient of $\alpha_{1} \mathbf{M}$ to $\beta_{2} \mathbf{M}$ concentration was $r=0.60(n=68)$. The urinary light chain and $\alpha_{1} \mathrm{M}$ concentration in multiple myeloma were less well correlated $(\mathrm{r}=0.35, \mathrm{n}=80)$. Crossed immunoelectrophoresis of the urinary $\alpha_{1} \mathrm{M}$ showed that in renal failure and in myelomatosis, including IgA myelomas, the $\alpha_{1} \mathrm{M}$ ran as a single peak that was not bound to other proteins.
ACUTE CHANGES IN RENAL TUBULAR FUNCTION Changes in urinary $\alpha_{1} \mathbf{M}$ concentrations during a period of acute renal tubular damage and its recovery are illustrated by considering the urinary low molecular weight protein excretion patterns after burns. Figure 3 shows a patient with a $30 \%$ superficial burn not requiring antibiotics. A study of a further 24 burn injury patients with 100 samples indicated that $\beta_{2} M$ and $R B P$ concentrations are highly correlated $(r=0.89)$ whilst the correlation is less for $\alpha_{1} M$ to $\beta_{2} M(r=0.55)$ or $\alpha_{1} M$ to RBP (r = $0.48)$. Generally the urinary $\alpha_{1} M, R B P$ and $\beta_{2} M$ concentrations follow the same pattern of increase and return to normal but the magnitude of change of $\beta_{2} M$ and RBP is two to three times greater than that of $\alpha_{1}$ M. NAG runs a parallel course but it appears to lag behind the changes in the reabsorption of lower molecular weight proteins by the proximal tubular cells. Urinary $\alpha_{1} \mathbf{M}$ concentrations in acute pancreatitis show a similar pattern to that in burns with an $\alpha_{1} \mathrm{M}$ to $\beta_{2} \mathrm{M}$ correlation coefficient of $\mathrm{r}=0.59$ and $\alpha_{1} \mathrm{M}$ to RBP correlation coefficient of 0.50 .

\section{Discussion}

The distribution of serum $\alpha_{1} \mathbf{M}$ in controls and patients with renal failure is similar to that recorded by other authors. ${ }^{112021}$ In normal subjects there is no diurnal variation of serum $\alpha_{1} \mathrm{M}$ concentrations. ${ }^{30}$

IgA myelomatosis is a condition in which the well established property of $\alpha_{1} \mathrm{M}$ to bind to $\operatorname{IgA}$ appears to influence strongly the blood concentrations of $\alpha_{1} \mathrm{M}$; this also seems to be an occasional effect in rheumatoid arthritis but not in liver disease where increases of the $\operatorname{IgA}$ concentrations are commonplace. This suggests the monomers and polymers of IgA do not bind $\alpha_{1} \mathrm{M}$ to the same extent. However, it is clear that it is the free $\alpha_{1} M$ that is filtered by the glomerulus as the relation of urinary $\alpha_{1} \mathrm{M}$ to light chain excretion is similar in $\operatorname{IgA}$ and IgG myelomas and electrophoretic analysis has demonstrated the $\alpha_{1} M$ excreted in the urine is an unbound protein.

Table 4 Relation between urinary $\alpha_{1} M$ and $\beta_{2} M$

\begin{tabular}{|c|c|c|c|c|c|c|}
\hline \multirow{2}{*}{$\begin{array}{l}\text { Urinary concentration } \\
\text { of } \alpha_{1} M \text { and } \beta_{2} M\end{array}$} & \multirow{2}{*}{$\begin{array}{l}\text { Chemical } \\
\text { workers }\end{array}$} & \multirow[t]{2}{*}{ Paraplegics } & \multirow{2}{*}{$\begin{array}{l}\text { Rheumatic } \\
\text { diseases }\end{array}$} & \multicolumn{2}{|c|}{ Bladder cancer } & \multirow{2}{*}{$\begin{array}{l}\text { Ileal } \\
\text { conduits }\end{array}$} \\
\hline & & & & $T_{1}+T i s$ & $T_{2}-T_{4}$ & \\
\hline $\begin{array}{l}\text { Normal } \alpha_{1} \mathbf{M} \\
\text { Normal } \beta_{2} \mathbf{M}\end{array}$ & 485 & 77 & 54 & 108 & 44 & 24 \\
\hline $\begin{array}{l}\text { Raised } \alpha_{1} M \\
\text { Normal } \beta_{2} M\end{array}$ & 11 & 14 & 15 & 16 & 11 & 4 \\
\hline $\begin{array}{l}\text { Normal } \alpha_{1} M \\
\text { Raised } \beta_{2} M\end{array}$ & 0 & 2 & 0 & 1 & 1 & 0 \\
\hline $\begin{array}{l}\text { Raised } \alpha_{1} M \\
\text { Raised } \beta, M\end{array}$ & 4 & 12 & 15 & 14 & 8 & 8 \\
\hline Total & 500 & 105 & 84 & 139 & 64 & 36 \\
\hline
\end{tabular}

Normal $=\alpha_{1} \mathrm{M}<15 \mathrm{mg} / \mathrm{g}$ creatinine; $\beta_{2} \mathrm{M}<2 \mathrm{mg} / \mathrm{g}$ creatinine by RID.

Raised $=\alpha_{1} M \geqslant 15 \mathrm{mg} / \mathrm{g}$ creatinine; $\beta_{2} M \geqslant 2 \mathrm{mg} / \mathrm{g}$ creatinine by RID. 


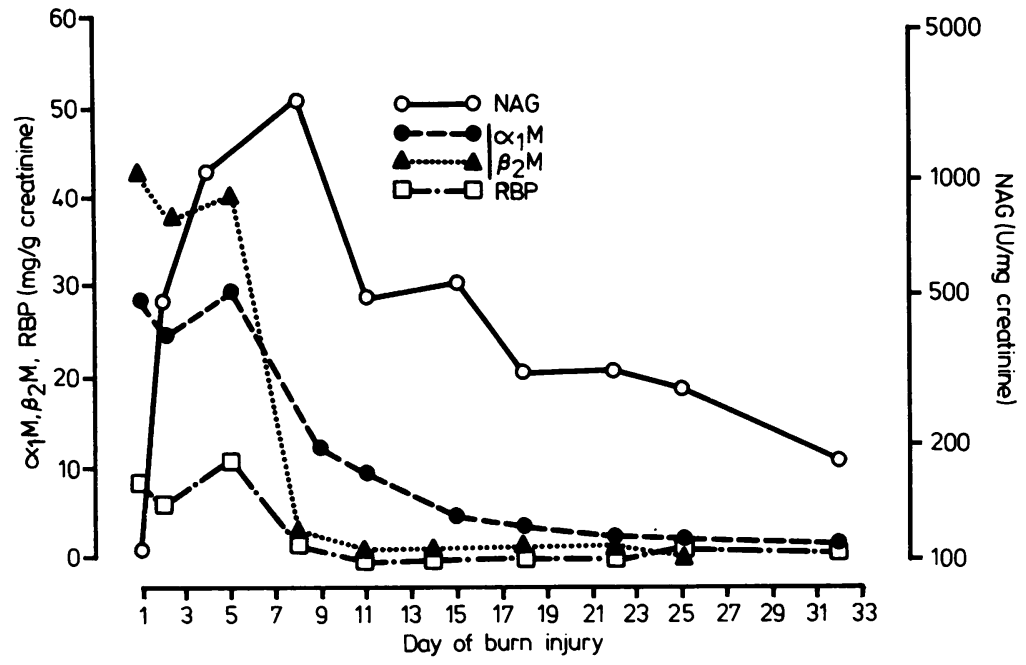

Fig. 3 Pattern of evolution of urinary low molecular weight protein excretion and NAG activities after a mild burn injury

Urinary excretion of $\alpha_{1} \mathbf{M}$ in normal subjects has been estimated to be $9 \mathrm{mg} / 24 \mathrm{~h}^{4}$ and $5.7 \mathrm{mg} / 24 \mathrm{~h}^{19}$ using RID and $10 \mathrm{mg} / \mathrm{l}^{15}$ and $1.3 \mathrm{mg} / 24 \mathrm{~h}$ using an electroimmunoassay. ${ }^{16}$ These figures reflect the different reference standards and methods used in the assays. Our assay, using the Behringwerke standard, for normal urine and serum concentrations gives similar values to those reported by Takagi et al. ${ }^{19}$ This study has shown that the measurement of urinary $\alpha_{1} \mathbf{M}$ can provide information about the renal filtration and reabsorption of low molecular weight protein. The SDS gel patterns and correlations with other low molecular weight proteins ( $R B P$ and $\beta_{2} M$ ) confirm that in the absence of renal failure a raised urinary $\alpha_{1} \mathbf{M}$ is an indicator of tubular proteinuria. When there is considerable reduction of the glomerular filtration rate the concentrations of $\alpha_{1} \mathrm{M}$ are increased in the serum and an increase of urinary excretion under these circumstances could be partly due to overload of the tubule and partly due to a mixed glomerular and tubular lesion. In practical terms in a patient with a serum creatinine $<200$ $\mu \mathrm{mol} / 1$, a urinary concentration of $\alpha_{1} \mathrm{M}$ of $\geqslant 15 \mathrm{mg} / \mathrm{g}$ creatinine is an indication of tubular proteinuria although an SDS gel is needed to confirm the diagnosis. In this respect, the $\alpha_{1} M$ test using RID is less sensitive than the measurement of urinary $\beta_{2} M$ by RIA and cannot demonstrate falls of 1 or $2 \%$ of tubular reabsorption efficiency which can be discriminated by the RIA or ELISA measurement of $\beta_{2} M$. However, the $\alpha_{1} M$ test has the advantage of simplicity, low cost and $\alpha_{1} M$ is stable in the urine over a range of $\mathrm{pH}$ found in routine practice. On the other hand, $\beta_{2} \mathrm{M}$ is unstable at $\mathrm{pH}<5.5$ and could give false-negative results if it is measured in acidic urine. ${ }^{1026}$ In this respect, $\alpha_{1} \mathrm{M}$ shows similar advantages to those suggested for RBP as a practical method of screening of renal tubular function. ${ }^{10}$ However, an RID assay for RBP is too insensitive to identify very small changes of tubular function but when tubular function is impaired by a factor of $10 \%$ or over, then concentrations of RBP and $\beta_{2} M$ are highly correlated. The measurement of urinary $\alpha_{1} M$ appears to be free from interference from the effects of urinary infection and haematuria or from the liberation of tissue breakdown products in bladder cancer. Whether the more recently developed radioimmunoassays or enzyme linked immunosorbent assays ${ }^{27}$ will have advantages for urine screening is uncertain. The assays have been modified for nephelometric techniques which could provide a rapid assay needed when there is a probability of occult acute tubular damage. ${ }^{31}$

The relation between urinary $\alpha_{1} \mathrm{M}$ concentrations and light chain excretion is of particular interest as measurement of $\alpha_{1} \mathrm{M}$ can provide an indication of the incidence and severity of tubular disorder that accompanies myelomatosis. This test has potential in helping to investigate the nephrotoxic effects of light chains that is evident in this series; as in other studies, ${ }^{28}$ not all light chain excretion, even when a large amount, will produce renal damage. The nephrotoxic effects of myelomatosis-in general $\alpha_{1} \mathrm{M}$ and light chain excretion are correlated, but these proteins can show marked discordance drawing attention to the non-nephrotoxic forms of light chain excretion $^{28}$ or tubular damage in the absence of increased light chain excretion. In monitoring of patients with myelomatosis urinary $\alpha_{1} \mathbf{M}$ measurements have some advantages, especially as the assay 
does not present the technical difficulties in measuring light chain excretion.

The interrelations of urinary $\alpha_{1} \mathbf{M}, \beta_{2} \mathbf{M}$, and RBP are all partially explained by consideration of the time-point during an acute event when the urine was sampled. In long-standing tubular proteinuria $\alpha_{1} \mathbf{M}$ excretion can be raised when there is a generalised abnormality of proximal tubular function affecting all proteins, or it can be part of a selective tubular proteinuria that seems to affect the relatively large low molecular weight protein such as $\alpha_{1}$-acid glycoprotein (MW 44000 daltons). ${ }^{29}$

The correlation of urinary $\alpha_{1} M$ and NAG excretion in acute tubular damage indicates that they can both reflect proximal tubular cell injury but the intensity of their disturbance as indicated by the failure to reabsorb a protein or the excessive discharge of NAG, a lysosomal enzyme, into the urine are not synchronous. In chronic tubular disorders the relation of the absorption of the low molecular weight proteins and the excretion of NAG are far more reliable. The very high NAG activities seen in acute lesions are rare. The precise interpretation of a high NAG is uncertain and depends on the clinical condition. For example, in paraplegia it would suggest an upper renal tract infection; in myelomatosis, an exacerbation of interstitial nephritis. High NAG activities are a well recognised feature of certain forms of drug-induced renal tubular damage, particularly that caused by aminoglycosides. ${ }^{13}$ The present studies suggest that the urinary measurement of $\alpha_{1} \mathrm{M}$ can be a useful method of screening populations in whom there is a risk of tubular proteinuria whatever the underlying cause.

$\mathrm{H} \mathrm{Yu}$ is supported by the Ministry of Education and Ningxia Medical College, Peoples' Republic of China; Y Yanagisawa is supported by the Shinshu University of Japan and MA Forbes is supported by the Yorkshire Cancer Research Campaign. We are grateful to Dr JAD Settle and Mr PH Smith for permission to investigate their patients and Dr WG Taylor for his help with the industrial survey. We wish to thank Behringwerke AG, Marburg, Germany, for the gift of the alpha-1-microglobulin antisera which is not available commercially.

\section{References}

' Berggard I, Bearn AG. Isolation and properties of a low molecular weight $\beta_{2}$-microglobulin occurring in human biological fluids. J Biol Chem 1968;243:4095-103.

${ }^{2}$ Berggard I, Peterson PA. Polymeric forms of free normal kappa and lambda light chains of human immunoglobulin. $J$ Biol Chem 1969;244:4299-307.

${ }^{3}$ Peterson PA, Berggård I. Isolation and properties of a human retinol binding transporting protein. $J$ Biol Chem 1971;246:25-33.
4 Ekström B, Berggård I. Human $\alpha_{1}$-microglobulin. Purification procedure, chemical and physiochemical properties. J Biol Chem 1977;252:8048-57.

${ }^{5}$ Maack T, Johnson V, Kau ST, Figueiredo J, Sigulem D. Renal filtration, transport and metabolism of low molecular weight proteins: a review. Kidney Int 1979;16:251-70.

- Piscator M. $\beta_{2}$-microglobulin in the diagnosis of chronic cadmium poisoning. In: Peterson PA, Lauwerys $R$, eds. $\boldsymbol{\beta}_{2-}$ microglobulin in proliferative disorders and heavy metal intoxication. Gent, Belgium: European Press, 1978:69-77.

${ }^{7}$ Iesato K, Wakashin M, Wakashin Y, Tojo S. Renal tubular dysfunction in minamata disease. Detection of renal tubular antigen and $\beta_{2}$-microglobulin in the urine. Ann Intern Med 1977;86:731-7.

${ }^{8}$ Fleming JJ, Child JA, Cooper EH, Hay AM, Morgan DB, Parapia $L$. Renal tubular damage without glomerular damage after cytotoxic drugs and aminoglycosides. Biomedicine 1980;33:251-4.

9 Schentag JJ, Plaut ME. Patterns of urinary $\beta_{2}$-microglobulin excretion by patients treated with aminoglycosides. Kidney Int 1980;17:654.

${ }^{10}$ Bernard AM, Lauwerys RR. Retinol binding protein in urine: a more practical index than urinary $\beta_{2}$-microglobulin for the routine screening of renal tubular function. Clin Chem 1981;27(10):1781-2.

" Takagi K, Itoh Y, Enomoto H, Koyamaishi Y, Maeoa K, Kawai T. A comparative study of serum $\alpha_{1}$-microglobulin and $\beta_{2}$-microglobulin levels in cancerous and other diseases. Clin Chim Acta 1980;108:277-83.

12 Price RG. Urinary $\mathrm{N}$-acetyl- $\beta$-D-glucosaminidase (NAG) as an indictor of renal disease. In: Dubach UC, Schmidt U, eds. Diagnostic significance of enzymes and proteins in urine. Bern: Hans Huber, 1979:150-63.

${ }^{13}$ Gibey R, Dupond JL, Alber D, des Floris RL, Henry JC. Predictive value of urinary $\mathrm{N}$-acetyl- $\beta$-D-glucosaminidase (NAG) alanine-aminopeptidase (AAP) and beta-2-microglobulin $\left(\beta_{2} M\right)$ in evaluating nephrotoxicity of gentamicin. Clin Chim Acta 1981;116:25-34.

14 Burchardt U, Haschen RJ, Krosch H. Clinical usefulness of enzyme determinations in urine. In: Dubach UC, Schmidt U, eds. Diagnostic significance of enzymes and proteins in urine. Bern: Hans Huber, 1979:106-12.

is Tejler L, Grubb AO. A complex-forming glycoprotein heterogeneous in change and present in human plasma, urine and cerebrospinal fluid. Biochim Biophys Acta 1976;439:8294.

${ }^{16}$ Svensson L, Ravsnkov U. $\alpha_{1}$-microglobulin. A new low molecular weight plasma protein. Clin Chim Acta 1976;76:415-22.

17 Ekström B, Peterson PA, Berggård I. A urinary and plasma $\alpha_{1}$-glycoprotein of low molecular weight: isolation and some properties. Biochem Biophys Res Commun 1975;65:1427.

${ }^{18}$ Takagi K, Kin K, Itoh Y, Kawai T, Kasahara T, Shimoda T, Shikata T. Tissue distribution of human $\alpha_{1}$-microglobulin. $J$ Clin Invest 1979;63:318-25.

19 Takagi T, Takagi K, Kawai T. Complete amino acid sequence of human $\alpha_{1}$-microglobulin. Biochem Biophys Res Commun 1981;98(4):997-1001.

${ }^{20}$ Kawai T, Takagi K. Human $\alpha_{1}$-microglobulin. Its physicochemical properties and clinical significance. Asian Med $J$ 1982;25:251-70.

${ }^{21}$ Berggård I, Ekström B, Akerström B. $\alpha$--microglobulin. Scand J Clin Lab Invest 1980;40,(Suppl 154):63-71.

${ }^{22}$ Mancini G, Carbonara AO, Heremans JF. Immunochemical quantitation of antigen by single radial immunodiffusion. Immunochem 1965;2:235-54.

${ }^{23}$ Leback DE, Walker PG. The fluorimetric assay of $\mathrm{N}$ acetyl- $\beta$-D-glucosaminidase. Biochem $J$ 1961;78:151-6.

24 Price RG, Dance N. The excretion of Nacetyl- $\beta$-D-glucosaminidase and $\beta$-galactosidase following surgery to the kidney. Clin Chim Acta 1970;27:65-72. 
${ }^{25}$ Pesce AJ, Bureisma I, Pollak VE. Rapid differentiation of glomerular and tubular proteinuria by sodium dodecyl sulfate polyacrylamide gel electrophoresis. Clin Chim Acta 1972;40:27-34.

${ }^{26}$ Evrin PE, Wibell L. The serum levels and urinary excretion of $\beta_{2}$-microglobulin in apparently healthy subjects. Scand J Clin Lab Invest 1972;29:69-74.

${ }^{27}$ De Fronzo RA, Cooke CR, Wright JR, Humphrey RL. Renal function in patients with multiple myeloma. Medicine 1978;57:151-66.

${ }^{28}$ Scarpioni L, Ballocchi S, Bergonzi G, et al. Glomerular and tubular proteinuria in myeloma. Relationship with Bence-Jones proteinuria. In: Migone L, ed. Contribution to nephrology 26 Basel: Karger, 1981:89-102.

${ }^{29}$ Boesken WH. Diagnostic significance of SDS-PAA- electrophoresis of urinary proteins: different forms of proteinuria and their correlation to renal disease. In: Dubach UC, Schmidt U, eds. Diagnostic significance of enzymes and proteins in urine. Bern: Hans Huber, 1979:235-48.

${ }^{30}$ Itoh Y. Diurnal variation of serum alpha-1-microglobulin in normal subjects. Nephron 1981;29:204.

${ }^{31}$ Matsunaga S, Umeki K, Nakagawa H, Ohtaki S. Experimental and clinical studies on determination of urinary low molecular weight proteins by laser nephelometer. Rinsho Byori 1981;29:502-6 (in Japanese).

Requests for reprints to: Prof EH Cooper, The Unit for Cancer Research, School of Medicine, Leeds LS2 9NL, England. 